\title{
TRADE OFF ANTARA UNIFORMITY DAN FLEXIBILITY DALAM PENGUNGKAPAN PELAPORAN TRIPLE BOTTOM LINE
}

\author{
Arin Pranesti \\ Program Studi Akuntansi, Fakultas Ekonomi \\ Universitas Negeri Yogyakarta \\ arinpranesti@uny.ac.id
}

\begin{abstract}
Abstrak: Trade Off Antara Uniformity dan Flexibility dalam Pengungkapan Pelaporan Triple Bottom Line. Pengungkapan yang lebih komprehensif yang tidak hanya berfokus pada pengungkapan laba menjadi hal yang krusial untuk diungkapkan oleh perusahaan. Baru-baru ini, pengungkapan entitas mengarah ke format pelaporan Triple Bottom Line (TBL). Penelitian ini bertujuan untuk mengetahui apakah dampak yang dapat ditimbulkan ketika konsep keseragaman dan fleksibilitas diterapkan pada pelaporan TBL. Penelitian ini merupakan penelitian kajian literature yang bersumber pada artikelartikel yang sesuai dengan topi penelitian untuk dianalisis lebih lanjut. Hasil penelitian menunjukkan bahwa permintaan untuk pelaporan komprehensif tidak diikuti oleh standar yang dibuat oleh standar terkait dewan. Dalam praktiknya, pelaporan TBL masih mengedepankan konsep pengungkapan penuh dan fleksibilitas, tetapi tidak mudah melakukan perbandingan antar-entitas. Pedoman untuk implementasi pelaporan TBL telah dibuat oleh organisasi nirlaba yang disebut Global Reporting Initiative (GRI). Beberapa peneliti menyarankan adanya keseragaman dalam pelaporan TBL, tetapi beberapa pihak mendukung fleksibilitas dalam pengungkapan pelaporannya.
\end{abstract}

Kata kunci: TBL, Pengungkapan, Keseragaman, Fleksibilitas, Keterbandingan

Abstract: Trade Off Between Uniformity and Flexibility in Triple Bottom Line Reporting Disclosure. A more comprehensive disclosure that does not only focus on disclosure of earnings is crucial to be disclosed by the company. Recently, entity disclosure leads to the Triple Bottom Line (TBL) reporting format. This study aims to determine the impact of implementing the concept of uniformity and flexibility to TBL reporting. This research is a literature review study referring to articles which are in accordance with research topics needing for further analysis. The results showed that requests for comprehensive reporting were not followed by standards set by the board's related standards. In practice, TBL reporting still promotes the concepts of full disclosure and flexibility, but it is not easy to conduct comparisons between entities. Guidelines for implementing TBL reporting have been developed by a non-profit organization called the Global Reporting Initiative (GRI). Some researchers suggest uniformity in TBL reporting, but some parties support flexibility in disclosure of reporting

Keywords: TBL, Disclosure, Uniformity, Flexibility, Comparability.

\section{PENDAHULUAN}

Pada awalnya penyediaan informasi suatu perusahaan merupakan suatu hal yang sensitif untuk diungkapkan oleh perusahaan kepada pihak eksternal, namun pada perkembangannya informasi kinerja perusahaan baik keuangan maupun non keuangan merupakan hal yang sangat penting bagi manajemen dan di luar manajemen untuk menilai baik atau tidaknya kinerja perusahaan. Menurut Statement of Financial Accounting Concepts (SFAC) Nomor 1 yang kemudian digantikan dengan SFAC No 8, informasi merupakan suatu biaya yang dikeluarkan oleh perusahaan, perusahaan akan mempertimbangkan cost and benefit atas penerbitan informasi, jika manfaat yang diterima melebihi dari biaya yang dikeluarkan, perusahaan akan secara sukarela mengungkapkan informasi yang ada tentang 


\section{JURNAL NOMINAL / VOLUME VIII NOMOR 2 / TAHUN 2019}

perusahaan kepada masyarakat luas. Penyediaan informasi yang dilakukan oleh manajemen yang pada awalnya hanya memenuhi fungsi akuntabilitas atau pertanggungjawaban manajemen namun sekarang telah bergeser fungsi untuk digunakan sebagai dasar pengambilan keputusan (Baridwan, 2011).

Pengungkapan mempunyai peran penting di dunia penelitian dan praktik akuntansi. Pengungkapan secara penuh adalah salah satu cara merespon kebutuhan akan informasi dari pihak eksternal. Pengungkapan berkaitan dengan cara pembeberan atau penjelasan hal-hal informatif yang dianggap penting dan bermanfaat bagi pemakai selain siapa saja yang dapat dinyatakan melalui laporan keuangan utama (Suwardjono, 2008). Pengungkapan dilakukan oleh entitas dengan tujuan agar informasi yang disediakan dapat berguna untuk pengambilan keputusan dan tidak bersifat misleading information (informasi yang menyesatkan) bagi user (Moonitz dalam Wolk, Dodd, dan Rozycki, 2013). Mc Cullers dan Schroeder (1982) menambahkan bahwa Moonitz menyatakan bahwa konsep pengungkapan harus mengandung dalam istilah yang mungkin paling luas yaitu mencakup (1) apa yang harus diungkapkan, (2) kepada siapa, dan (3) bagaimana pengungkapan harus dibuat.

Beberapa tahun terakhir bidang akuntansi sosial (social accounting) dan sustainability reporting menjadi bidang penelitian akuntansi yang banyak dibahas oleh para akademisi (Jackson et al, 2011; Milne dan Gray, 2013; Shnayder et al, 2015; Khomba dan Vermaak, 2012). Konsep tersebut muncul dari tuntutan dan harapan masyarakat tentang peran perusahaan dalam masyarakat (Susanto dan Tarigan, 2013). Financial Accounting Standards Board (FASB) dalam SFAC No.8 mengungkapkan primary user pelaporan keuangan adalah investor dan kreditor. Menurut Baridwan (2011) pada konsep akuntansi sosial dan sustainability reporting perusahaan menerapkan konsep stakeholder yang berarti bahwa perusahaan telah melakukan kontrak sosial tidak hanya dengan kreditor dan investor, tetapi juga masyarakat sehingga perlu dilakukan pertanggungjawaban akan aktivitas perusahaan kepada masyarakat.

Pada tahun 1966 American Accounting Associaton menerbitkan A Statament of Basic Accounting Theory (ASOBAT) dalam Wolk, Dodd, dan Rozycki (2013) yang menyebutkan ada 4 tujuan akuntansi yaitu (1) membuat keputusan berkaitan dengan penggunaan sumberdaya yang terbatas dan untuk menentukan tujuan dan sasaran, (2) Secara efektif mengarahkan dan mengendalikan efektivitas sumberdaya manusia dan material organisasi, (3) memelihara dan melaporkan pemiliharaan sumberdaya, dan (4) memfasilitasi fungsi dan pengendalian sosial. Dari tujuan tersebut 


\section{JURNAL NOMINAL / VOLUME VIII NOMOR 2 / TAHUN 2019}

disebutkan adanya tujuan sosial yang berkaitan dengan akuntansi sosial dan fungsi pertanggungjawaban kepada pihak selain investor dan kreditor sehingga pada dasarnya arahan informasi akuntansi tidak hanya untuk tujuan keuangan saja namun juga meliputi tujuan non keuangan (Baridwan, 2011).

Perkembangan pelaporan pada era globalisasi memberikan fakta bahwa sudah banyak perusahaan dari berbagai negara yang berupaya mengadopsi pengungkapan pelaporan keuangan yang tidak hanya berfokus pada single bottom line yaitu berfokus utama laba akuntansi (profit) income). Pergeseran pemahaman akan hal tersebut dapat terlihat pada jumlah penyedia laporan yang melibatkan perspektif lain selain keuangan. Jackson et al (2011) berpendapat pertumbuhan akan sudut pandang yang lebih luas dari "world sustainability" dapat dilihat dari jumlah perusahaan yang memulai pelaporannya lebih dari operasi keuangan saja. Terdapat beberapa negara seperti Australia, Inggris, Jepang, Perancis, New Zealand, Afrika Selatan, Switzerland dan Amerika Serikat mempromosikan pelaporan berkelanjutan dalam bentuk Triple Bottom Line (kemudian disingkat: TBL) Reporting (Jackson et al, 2011). TBL merupakan bentuk laporan yang komprehensif yang tidak hanya mengandung unsur keuangan saja tetapi juga mengungkapakan unsur non keuangan yaitu sosial dan lingkungan hidup. Terdapat 3 fokus utama TBL yaitu people, planet, and profit (Global Reporting Initiative, 2006). People merujuk pada aktivitas sosial, planet merujuk aktivitas lingkungan, dan profit merujuk pada aktivitas ekonomi dimana seluruh aspek dari ketiga aktivitas diungkapkan pada laporan TBL.

Informasi yang disampaikan oleh penyaji laporan keuangan (preparer) dapat diungkapkan baik secara wajib (mandatory) maupun sukarela (voluntary). Pada prinsipnya, pelaporan TBL adalah bersifat sukarela (voluntary), berbeda dengan pengungkapan laporan keuangan di Amerika Serikat yang bersifat mandatory yang disyaratkan oleh Securities and Exchange Commission (SEC) yang mewajibkan perusahaan yang terdaftar di bursa untuk mengungkapkan laporan keuangan dengan standar yang telah ditentukan.

Beberapa peneliti mengungkapkan bahwa TBL belum mempunyai standar layaknya standar pelaporan keuangan, dimana pelaporan keuangan harus disusun berdasarkan standar yang ada agar berguna bagi pemakai laporan. Menurut Rajafi dan Irianto (2007) sampai saat ini, belum terdapat standar atau panduan yang berterima umum mengenai praktik triple bottom line reporting sehingga jenis informasi yang dilaporkan mengenai ketiga aspek dalam triple bottom line reporting juga beragam dari satu perusahaan ke perusahaan lainnya. Hal tersebut juga diungkapkan oleh Panduan 


\section{JURNAL NOMINAL / VOLUME VIII NOMOR 2 / TAHUN 2019}

TBL yang dikeluarkan oleh Association of Australia's Senior Finance Executives from the nation's business enterprise merupakan panduan yang sudah diusahakan untuk diimplementasikan pada perusahaanperusahaan namun belum dapat diseragamkan di seluruh negara.

Adanya usaha untuk menyeragamkan format pelaporan TBL tidak membuat semua akademisi dan praktisi setuju. Slaper dan Hall (2011) mengungkapkan bahwa TBL bersifat luwes (flexible) yang memperbolehkan organisasi untuk menerapkan konsep dalam cara yang sesuai dengan kebutuhan spesifiknya. Namun disisi lain, keleluasaan dalam penyusunan laporan atau kurangnya penyeragaman atas pelaporan $\mathrm{TBL} /$ sustainability reporting dan penjaminan akan mengurangi daya banding, keefektifan, dan keakuratan pelaporan (Guo dan Yang, 2014). Lako (2014) menyebutkan bahwa pada tahun 2020, penerapan model pelaporan tersebut direncanakan akan diwajibkan bagi semua korporasi di dunia, termasuk koporasi Indonesia. Hal tersebut merupakan suatu pekerjaan rumah bagi profesi akuntan untuk membuat standar sesuai dengan kondisi realita yang ada.

Beberapa penelitian terdahulu mengungkapkan bahwa masih terdapat alasan yang tumpang tindih mengenai penetapan kebijakan berdasarkan konsep fleksibilitas atau penyeragaman pelaporan TBL oleh beberapa peneliti (Slaper dan Hall
2011 dan Guo dan Yang, 2014). Hal tersebut mendorong dilakukan penelitian ini yang bertujuan untuk mengetahui apakah dampak penerapan konsep flexibility dan comparability pada pelaporan TBL. Kajian ini akan berfokus pada (1) pemahaman mengenai triple bottom line (TBL) reporting sebagai bagian dari akuntansi sosial (2) konsep-konsep yang mendasari konsep keseragaman dan flexibility yang dikaitkan dengan konsep pelaporan yang dapat diperbandingkan (comparable). Di bagian akhir kajian akan berisi pandangan penulis berdasarkan literatur terdahulu mengenai kelebihan dan kelemahan penyeragaman atau fleksibelitas pelaporan TBL agar pelaporan TBL dapat diperbandingkan.

\section{KAJIAN LITERATUR}

TBL Reporting Sebagai Bagian Akuntansi Sosial

\section{a. Corporate Social Responsibility}

Sejak dikeluarkannya Undang-Undang No. 40 Tahun 2007 tentang Perseroan Terbatas (UUPT) perusahaan di Indonesia mulai gencar melakukan aktivitas yang berkaitan dengan tanggungjawab sosial perusahaan (Corporate Social Responsibility-CSR). Pasal 66 UUPT menyatakan bahwa laporan tanggungjawab sosial perusahaan merupakan salah satu laporan wajib yang harus disusun oleh perusahaan yang terintegrasi dalam laporan tahunan (annual report) perusahaan. Laporan tanggung jawab sosial perusahaan perseroan di Indonesia masih terbatas pada 


\section{JURNAL NOMINAL / VOLUME VIII NOMOR 2 / TAHUN 2019}

perusahaan yang bergerak dalam bidang usaha sumberdaya alam. Kewajiban pelaporan yang disyaratkan oleh perundangundangan menuntut profesi akuntansi untuk membuat aturan yang mencakup aturanaturan yang berkaitan dengan panduan pengakuan, pencatatan, hingga pelaporan dan pengungkapan akuntansi dalam suatu pelaporan keuangan yang handal (Lako, 2014).

Dalam perkembangan perusahaan bertaraf dunia, praktik pelaporan akuntansi sosial tidak hanya dilakukan oleh perusahaan yang bergerak dalam bidang sumber daya alam saja, kelompok bisnis telah memulai sebuah perjalanan menuju pelaporan yang meningkatkan transparansi dan akuntabilitas (Fowler, 2003). Elkington (2004) menyebutkan terdapat tujuh aspek revolusi keberlanjutan yang akan bergerak dan melakukan proses transisi untuk menjadi lebih baik. Tujuh aspek tersebut adalah sebagai berikut.

Tabel 1. Tujuh Aspek Revolusi Keberlanjutan

\begin{tabular}{|c|c|c|}
\hline Component & $\begin{array}{c}\text { Old } \\
\text { Paradigm }\end{array}$ & $\begin{array}{c}\text { New } \\
\text { Paradigm }\end{array}$ \\
\hline Markets & $\begin{array}{l}\text { Complianc } \\
e\end{array}$ & $\begin{array}{l}\text { Competitio } \\
n\end{array}$ \\
\hline Values & Hard & Soft \\
\hline $\begin{array}{l}\text { Transparanc } \\
y\end{array}$ & Closed & Open \\
\hline $\begin{array}{l}\text { Life Cycle } \\
\text { Technology }\end{array}$ & Product & Function \\
\hline Partnerships & Subversion & Symbiosis \\
\hline Time & Wider & Longer \\
\hline $\begin{array}{l}\text { Corporate } \\
\text { Governance }\end{array}$ & Exclusive & Inclusive \\
\hline
\end{tabular}

Sumber: Elkington (2004) Jackson et al (2011) berpendapat peningkatan permintaan dari pemangku kepentingan akan informasi yang lebih ekstensif mengenai kegiatan operasi dan keuangan perusahaan mendorong beberapa perusahaan untuk memasukkan informasi dalam informasi akuntansi keberlanjutan (sustainability accounting). Hal tersebut berdampak pada pergerakan ke arah pengungkapan yang lebih komprehensif dari kinerja perusahaan termasuk faktor lingkungan, sosial, dan ekonomi.

\section{Triple Bottom Line Reporting}

Slaper dan Hall (2011) berpendapat bahwa John Elkington berupaya untuk mengukur keberlanjutan (sustainability) selama pertengahan 1990-an yang mengusulkan sebuah rerangka baru untuk mengukur kinerja dalam perusahaan Amerika. Sistem pelaporan keuangan tradisional telah bergerak dalam takaran pelaporan singlebottom line (SBL) dalam bentuk profitabilitas (Khomba dan Vermaak, 2012). Terdapat beberapa argumen bahwa sistem pelaporan perusahaan tidak hanya berfokus pada SBL saja namun seharusnya dilaporkan dalam 3 elemen yang terdiri dari ekonomi (finansial) yang tetap mempertahankan pengukuran tradisional atas laba, return on investment, dan pemegang saham serta termasuk dimensi sosial dan elemen lingkungan yang kemudian disebut Triple 


\section{JURNAL NOMINAL / VOLUME VIII NOMOR 2 / TAHUN 2019}

Bottom Line (Khomba dan Vermaak, 2012; Slaper dan Hall, 2011).

TBL merupakan rerangka dari pelaporan berkelanjutan (Sustainability Reporting) yang digunakan banyak perusahaan untuk melaporkan tiga dimensi yang dimaksud. Dalam buku Sustainability: A Guide to Triple Bottom Line Reporting yang ditulis oleh Fowler et al (2003), konsep pelaporan TBL merujuk pada publikasi informasi ekonomi, sosial, dan lingkungan yang terintegrasi pada satu penyajian yang merefleksikan aktivitas dan outcome terkait 3 dimensi kinerja perusahaan. Sebagai contoh dalam industri pengepakan makanan, berdasarkan penelitin yang dilakukan oleh Shnayder et al (2015) perusahaan yang melaksanakan program CSR melakukan pelaporan melalui pelaporan berkelanjutan (sustainability reporting) yang dilaporkan dan dianalisis menggunakan rerangka TBL dengan melibatkan tiga dimensi dan berguna untuk menentukan aspek mana dari kategori tersebut yang harus dikembangkan oleh perusahaan namun memiliki jangkauan yang terbatas.

Pelaporan keuangan tradisional yang baru memuat informasi keuangan dengan primary user-nya adalah investor dan kreditor, telah bergeser pada laporan keuangan yang berhubungan mengenai kegiatan operasional ekonomi perusahaan dan dampaknya baik secara langsung maupun tidak langsung kepada pemangku kepentingan dan masyarakat secara umum dalam operasi yang dilakukan.

\section{b. Konsep Pengungkapan (Disclosure Concept)}

Wolk, Dodd, dan Rozycki (2013) berpendapat bahwa pengungkapan merujuk pada penyajian informasi keuangan yang relevan baik dari dalam maupun luar batang tubuh laporan keuangan itu sendiri, termasuk metode yang digunakan dalam laporan keuangan dimana terdapat lebih dari datu pilihan yang ada atay pilihan yang tidak biasa dan inovatif atas metode yang digunakan sedangkan dalam SFAC No. 5 pengungkapan dijelaskan sebagai penyajian informasi dengan cara lebih dari pengakuan dalam laporan keuangan yang berlawanan dengan pengakuan dalam laporan keuangan itu sendiri. Suwardjono (2008), berpendapat bahwa pelaporan keuangan meliputi penyampaian informasi yang wajib secara luas (mandatory) dan sukarela (voluntary).

SFAC No.5 juga membatasi ruang lingkup informasi yang dapat diungkapkan oleh perusahaan yaitu laporan keuangan (financial statements) sebagai laporan inti yang disampaikan oleh pihak perusahaan kepada luar entitas. Selain itu, terdapat laporan yang bermanfaat bagi pihak luar entitas yang dapat disediakan oleh perusahaan yaitu:

1. Catatan atas laporan keuangan (notes to financial statements) 


\section{JURNAL NOMINAL / VOLUME VIII NOMOR 2 / TAHUN 2019}

2. Informasi pelengkap (supplementary information)

3. Cara pelaporan keuangan lain (other means of financial reporting)

4. Informasi lain (other information)

Faktanya, pelaporan keuangan yang bersifat mandatory oleh dewan standar hanyalah laporan keuangan dan Catatan atas Laporan Keuangan (CaLK) sedangkan ketiga laporan lain belum mempunyai standar yang jelas, namun peningkatan permintaan dari pemangku kepentingan dan masyarakat secara luas mengenai kebutuhan informasi akan penggunaan sumberdaya perusahaan membuat perusahaan secara sukarela melaporkan informasi selain laporan keuangan.

\section{c. Keterbandingan (Comparability) dalam}

\section{Konsep Uniformity dan Flexibility}

Informasi yang dilaporkan dalam pelaporan keuangan harus mengandung karakteristik kualitatif yang tertuang dalam SFAC No. 8 tentang Rerangka Konseptual Pelaporan Keuangan dimana pelaporan keuangan harus relevan dan faithful representation, kegunaan informasi pada pelaporan akan meningkat apabila pelaporan juga dapat dibandingkan (comparable), dapat diverifikasi (verifiable), tepat waktu (timeliness), dan dapat dipahami (understandability).

Keterbandingan (comparability) merupakan salah satu unsur dari karakteristik kualitatif pelaporan keuangan yang dapat meningkatkan manfaat pengguna pelaporan keuangan. Dalam artian, semakin dapat dibandingkan maka pelaporan keuangan yang disediakan entitas akan semakin bermanfaat bagi pengguna. Pengertian keterbandingan menurut SFAC No. 8 QC21 adalah sebagai berikut:

Comparability is the qualitative characteristic that enables users to identify and understand similarities in, and differences among, items. Unlike the other qualitative characteristics [verifiability, timeliness and understandability], comparability does not relate to a single item. A comparison requires at least two items.

Keterbandingan menurut SFAC dilakukan dengan membandingkan setidaknya dua item sehingga keterbandingan tidak dapat berdiri sendiri seperti karakteristik kualitatif lainnya.

Dalam literatur akuntansi, keterbandingan dipandang dari sudut user laporan, bukan dari sudut pandang preparer. Hendriksen dan van Breda (2001), Keterbandingan dapat diupayakan dengan melakukan analisis perbandingan antar waktu (time series) dalam satu perusahaan dengan konsep konsistensi (consistency) sedangkan dalam untuk analisis crosssection digunakan ide keseragaman (uniformity). Wolk, Dodd, dan Rozycki (2013) menambahkan bahwa keterbandingan merupakan prinsip berorientasi output (output-oriented principles) dipandang dari segi pengguna, sedangkan konsistensi dan 


\section{JURNAL NOMINAL / VOLUME VIII NOMOR 2 / TAHUN 2019}

keseragaman dipandang dari segi penyaji laporan keuangan.

Definisi konsistensi (consistency) dan keseragaman (uniformity) tidak dijelaskan oleh FASB namun dalam SFAC No. 8 menyebutkan bahwa:

... Consistency refers to the use of the same methods for the same items, either from period to period within a reporting entity or in a single period across entities.

Comparability is not uniformity.... Comparability of financial information is not enhanced by making unlike things look alike any more than it is enhanced by making like things look different

Dari paragraf tersebut dijelaskan bahwa konsistensi dan keseragaman bukan merupakan keterbandingan, hanya saja keduanya dapat meningkatkan keterbandingan laporan keuangan. Selanjutnya Wolk et al (2013) menyebutkan bahwa keterbandingan bergantung secara besar kepada jumlah keseragaman yang tertera dalam pencatatan transaksi dan penyajian laporan keuangan namun Simmons (1967) menjelaskan keseragaman adalah istilah yang lebih terikat dan mengimplikasikan akan adanya kurangnya variasi dalam persiapan dan penyajian laporan keuangan. Komparabilitas antar perusahaan dan konsistensi dalam pengaplikasian metode-metode sepanjang waktu meningkatkan nilai informasi dari perbandingan-perbandingan antara kesempatan ekonomi dan kinerja relatif ekonomi. Signifikansi informasi khususnya informasi kuantitatif bergantung pada kemampuan pengguna untuk mengaitkan hal tersebut kepada perusahaan pesaing. (Mc Cullers dan Schroeder, 1982).

Menurut Wolk, Dodd, dan Rozycki (2013) interpretasi dari konsep keseragaman adalah sebagai berikut:

1. Sekelompok keseragaman dari prinsipprinsip untuk semua perusahaan, dengan interpretasi dan aplikasi yang berakhir pada entitas individual.

2. Perlakuan akuntansi yang serupa mempersyaratkan dalam situasi serupa secara luas, tanpa memperhitungkan lingkungan berbeda yang mungkin ada (keseragaman yang kaku/ rigid uniformity)

3. Perlakuan akuntansi yang memperhitungkan perbedaan lingkungan ekonomi dalam transaksi yang serupa secara luas (keseragaman yang terbatas/ finite uniformity)

Di lain sisi, Meek dan Sandagaran (1990) menyebutkan bahwa keseragaman dan keterbandingan memiliki tujuan yang berbeda. Tujuan keseragaman sering diartikan secara implisit sebagai penyajian pelaporan keuangan oleh organisasi yang berbeda, dengan menggunakan prosedur akuntansi, konsep pengukuran, klasifikasi dan metode pengungkapan yang sams sebagai mana format dasar yang sama dalam laporan sedangkan keterbandingan 


\section{JURNAL NOMINAL / VOLUME VIII NOMOR 2 / TAHUN 2019}

memfasilitasi pembuatan prediksi dan keputusan keuangan oleh kreditor, investor, dan lainnya.

Menurut Belkaoui (2000), keseragaman mempunyai makna penggunaan prosedur yang sama oleh perusahaan yang berbeda. Tujuan yang akan dicapai dalam keterbandingan laporan keuangan adalah dengan mengurangi keragaman karena penggunaan prosedur akuntansi yang berbeda oleh perusahaan yang berbeda. Menurut Belkaoui (2000) prinsip yang mendukung untuk keseragaman adalah tuntutan bahwa hal tersebut harus:

1. Mengurangi keanekaragaman penggunaan prosedur akuntansi dan ketidakcukupan praktik akuntansi

2. Memungkinkan adanya perbandingan yang berarti dari laporan keuangan dalam perusahaan yang berbeda.

3. Memulihkan kembali kepercayaan diri pengguna laporan keuangan

4. Mengarah pada campur tangan dan peraturan pemerintah dalam praktik akuntansi.

Di lain sisi, Hendriksen dan van Breda (2001) berpendapat bahwa terdapat beberapa pendapat yang bertentangan dengan keseragaman didasarkan pada tuntutan mengenai:

1. Dapat melanggar hak dan kebebasan dasar manajemen.

2. Dapat menempatkan akuntansi dalam sebuah "straitjacket" atas aturan dan prosedur yang dapat membuat laporan keuangan kurang dapat dibandingkan.

3. Dapat menahan perubahan dan mencegah adanya perubahan yang diinginkan.

Pandangan lain mengenai praktik pelaporan keuangan adalah mengenai konsep flexibility. Ortega (2012) berpendapat bahwa flexibility dapat menghasilkan alternatif dalam metode akuntansi yang diperbolehkan oleh standar sebagaimana kurangnya persyaratan yang jelas, panduan yang jelas, dan pelaporan fenomena ekonomi. Praktik flexibility memungkinkan untuk memilih metode dan format pelaporan yang berbedabeda sesuai dengan keinginan manajemen. Belkaoui (2000) berpendapat terdapat dukungan utama untuk fleksibelitas adalah mengacu pada:

1. Penggunaan prosedur akuntansi yang seragam untuk merepresentasikan item yang sama yang terjadi dalam banyak kasus dapat memunculkan risiko penyembunyian perbedaan yang penting diantara kasus-kasus.

2. Komparabilitas adalah tujuan Utopia: "hal tersebut tidak dapat dicapai dengan adopsi aturan perusahaan yang tidak akan mendapatkan cara pencatatan yang cukup atas situasi faktual yang berbeda

3. "perbedaan dalam kondisi" atau "circumstantial variables" yang menimbulkan perlakuan yang berbeda sehingga pelaporan perusahaan dapat 


\section{JURNAL NOMINAL / VOLUME VIII NOMOR 2 / TAHUN 2019}

merespon pada kondisi dimana transaksi dan kejadian terjadi.

International Accounting Standards Board (IASB) dalam IASB Agenda ref 11F (2015) menyatakan bahwa flexibility secara umum berkaitan dengan: (1) penyajian dan klasifikasi item dan subtotal dalam laporan keuangan utama dan kemudian tidak dijumlahkan dalam catatan, dan (2) terminologi dan definisi yang digunakan untuk mengidentifikasi dan mendeskripsikan item yang penting. Flexibility dapat mengurangi keterbandingan antar perusahaan karena perbedaan yang terjadi dalam pemilihan metode akuntansi dan pelaporan akuntansi setiap perusahaan sehingga sangat sulit bagi pengguna dalam melakukan tindakan pembandingan atas laporan yang diterbitkan setiap perusahaan apabila flexibility diterapkan.

\section{METODE PENELITIAN}

Metode penelitian yang digunakan dalam penelitian ini adalah kajian literatur dengan mengumpulkan teori, data-data penelitian atau temuan pada penelitian sebelumnya dari berbagai sumber yang berkaitan dengan topik penelitian yang akan dikaji. Kajian literatur dalam hal ini dilakukan tanpa melakukan uji empiris.

\section{HASIL PENELITIAN DAN \\ PEMBAHASAN}

Informasi yang diberikan oleh entitas harus memiliki manfaat bagi penggunanya. Menurut Suwardjono (2008) informasi dikatakan mempunyai nilai (kebermanfaatan keputusan) apabila informasi tersebut: (1) Menambah pengetahuan pembuat keputusan tentang keputusan yang akan di masa lalu, sekarang, dan masa mendatang, Menambah keyakinan user mengenai probabilitas terealisasinya suatu harapan dalam kondisi ketidakpastian, dan (3) Mengubah keputusan atau perilaku para pemakai. Informasi tentang perusahaan tertentu meningkat secara tajam dalam hal kegunaannya jika hal tersebut dapat dibandingkan dengan informasi yang serupa mengenai perusahaan lain dan dengan informasi yang sama tentang perusahaan yang sama untuk jangka waktu tertentu (Mc Cullers dan Schroeder, 1982).

Dalam pelaporan TBL perusahaan dapat mengungkapkan informasi selengkaplengkapnya mengenai 3 elemen pelaporan TBL yaitu mengenai 3P (people, planet, and profit). Pengungkapan elemen lain selain laporan keuangan sebenarnya telah ada dalam standar akuntansi keuangan yang termaktub dalam PSAK No.01 Revisi 2009 paragraf 9 yang berbunyi:

Perusahaan dapat pula menyajikan laporan tambahan seperti laporan mengenai lingkungan hidup dan laporan nilai tambah (value added 


\section{JURNAL NOMINAL / VOLUME VIII NOMOR 2 / TAHUN 2019}

statement), khususnya bagi industri dimana faktor-faktor lingkungan hidup memegang peranan penting dan bagi industri yang menganggap pegawai sebagai kelompok pengguna laporan yang memegang peranan penting

\section{Perkembangan pelaporan TBL} memunculkan suatu permasalahan baru yaitu standar akuntansi tentang 3 pilar dalam pelaporan tersebut. Hasil penelitian Khomba dan Vermaak (2012) yang berjudul Relevance of financial reporting systems: Single bottom line or triple-bottom line juga menyebutkan bahwa perlu adanya telaah dan desain ulang tentang prinsip dan kebijakan akuntansi dan keuangan sehingga hal tersebut dapat disejajarkan dengan membuat sistem pelaporan TBL.

$$
\text { Lako (2014) mengungkapkan }
$$
terdapat 3 aspek dalam akuntansi yang perlu direformasi dalam menghadapi tuntutan akan pelaporan TBL yaitu:

1. Dewan standar perlu untuk merumuskan rerangka konseptual (conceptual framework), tujuan dan sasaran, serta prinsip-prinsip dasar akuntansi berkelanjutan

2. Dewan standar perlu melakukn reformasi format pelaporan akuntansi menuju format Pelaporan Berkelanjutan (integrasi pelaporan keuangan, sosial, lingkungan dan tatakelola)

3. Standar Akuntansi Keuangan menuju Standar Akuntansi Berkelanjutan yang meliputi pengakuan, perlakuan akuntansi, pencatatan, pengukuran dan pelaporan, serta pengungkapan informasi sosial dan lingkungan disertakan dengan informasi lainnya.

Salah satu bentuk tindakan yang harus dilakukan oleh dewan standar adalah membuat kebijakan mengenai panduan format pelaporan atas output yang dihasilkan dari elemen pelaporan TBL. Berdasarkan penelitian yang dilakukan oleh Guo dan Yang (2014) ditemukan adanya format dan pola pelaporan berbeda di antara 30 perusahaan Dow-Jones di Amerika. Hal tersebut menunjukkan bahwa belum adanya panduan atau standar yang jelas dalam hal pelaporan TBL. Pelaporan TBL menjadi tren yang dilakukan oleh perusahaan global untuk meningkatkan kuantitas pengungkapan. Namun sayangnya, saat ini belum ada format dan panduan yang jelas mengatur TBL sehingga output pelaporan TBL di antara perusahaan menjadi sangat bervariasi. Tidak adanya keseragaman dalam pengungkapan pelaporan TBL menimbulkan keadaan yang leluasa (flexibility) dalam melaksanakan pelaporan TBL yang dapat mengurangi adanya keterbandingan dan kurang dapat memberikan nilai lebih akan informasi yang diungkapkan oleh masing-masing perusahaan.

Lako (2014) menyatakan pada tahun 2020, direncanakan pelaporan TBL dan akuntansi berkelanjutan menjadi agenda 


\section{JURNAL NOMINAL / VOLUME VIII NOMOR 2 / TAHUN 2019}

wajib bagi semua perusahaan di dunia. Pada saat ini, sedang difinalisasikan draft International Sustainability Reporting Standards (ISRS) yang akan menjadi pedoman atau standar global bagi perusahaan dalam melakukan penyusunan pelaporan berkelanjutan. Apabila pelaporan berkelanjutan dibuat suatu standar yang mengaturnya maka hal tersebut akan mengarah pada proses penyusunan pedoman yang hasilnya nanti akan digunakan sebagai acuan pembuatan pelaporan berkelanjutan di seluruh negara sehingga pelaporan TBL akan bersifat mandatory (wajib). Standar yang mengatur akuntansi berkelanjutan menjadi bersifat uniform (seragam). Ball (2006) mengingatkan bahwa sebenarnya tidak ada teori yang tetap dalam penilaian kelebihan dan kekurangan dalam mengadopsi seperangkat standar akuntansi global. Hal tersebut didasarkan akan kebutuhan masingmasing korporasi yang berbeda sehingga perlu dilakukan pertimbangan matang dalam melakukan adopsi suatu standar.

Regulasi yang dibuat mengenai pelaporan TBL tentu akan membuat suatu pro dan cons. Satu pihak akan setuju (pro) karena dapat mempermudah pengguna laporan dan meningkatkan keterbandingan di antara keduanya. Pihak lain akan menolak (cons) karena kebebasan dalam pengungkapan laporannya akan dibatasi. Perlakuan akuntansi terjadi perdebatan implementasi penggunaan uniformity atau flexibility yang harus digunakan oleh penyaji laporan keuangan.

Belkaoui (2000) mengungkapkan solusi trade off dapat dilakukan dengan meningkatkan uniformity dengan memperkecil adanya keragaman (variasi) dalam praktik-praktik akuntansi dan pada waktu yang sama, memperbolehkan pengakuan yang sesuai dengan peristiwa pasar dan ekonomi secara khusus kepada perusahaan dan industri dengan hubungan yang sesuai atas keadaan ekonomi tertentu dengan teknik akuntansi terkait. Namun terdapat penelitian dari Ortega (2012) yang meneliti mengenai kebijakan standar IFRS bahwa Ortega tidak menemukan flexibility dari standar akuntansi lokal berdampak secara signifikan terhadap perubahan keterbandingan di dalam negara dalam hal adopsi kebijakan internasional.

Simmons (1967) menyebutkan bahwa faktor penting untuk mencapai cerminan yang setara dalam keterbandingan adalah penyajian laporan yang setara dan pengukuran yang setara. Penyajian laporan yang setara oleh dua perusahaan dapat dicapai apabila terdapat kondisi berikut ini:

1. Caption (catatan/ tulisan) laporan yang sama digunakan oleh kedua perusahaan (akibat dari ini adalah caption laporan yang berbeda seharusnya digunakan untuk kondisi ekonomi yang berbeda)

2. Klasifikasi laporan yang sama diikuti oleh kedua perusahaan 


\section{JURNAL NOMINAL / VOLUME VIII NOMOR 2 / TAHUN 2019}

3. Informasi detail yang sama diberikan oleh kedua perusahaan

sedangkan pengukuran yang setara oleh dua perusahaan dengan mempertimbangkan kondisi ekonomi dapat dicapai apabila: (1) Dasar penilaian yang sama digunakan oleh kedua perusahaan, (2) Unit pengukuran yang sama digunakan oleh kedua perusahaan, (3) Prosedur akuntansi digunakan oleh kedua perusahaan.

Dari pendapat Simmons dapat ditarik kesimpulan bahwa sebenarnya perlu adanya penyetaraan dari dua laporan untuk dapat dicapai suatu keterbandingan. Pelaporan TBL diharuskan memiliki suatu format yang jelas dan terukur untuk dapat diperbandingkan, sehingga pelaporan TBL tidak dapat dilaporkan dengan cara yang berbeda-beda (flexible) antar perusahaan. Hal tersebut bermakna bahwa seharusnya pelaporan TBL seharusnya memiliki keseragaman (uniform). Wolk, Dodd, dan Rozycki (2013) menyebutkan bahwa keseragaman dapat dikelompokkan dalam dua situasi yaitu rigid uniformity dan finite uniformity. Rigid uniformity dapat diterapkan dalam situasi dimana kondisi ekonomi tidak dapat ditentukan sehingga standar harus jelas sedangkan finite uniformity dapat diterapkan apabila kondisi ekonomi yang relevan (relevant circumstances) dapat diidentifikasi sehingga standar dapat memberikan kriteria tambahan untuk merujuk pada satu perlakuan yang sesuai dengan relevant circumstancesnya.

Menurut Gray (2010) dalam Guo dan Yang (2015), perspektif kritis pada akuntansi pelaporan berkelanjutan (TBL) adalah ketiadaan keadaan yang saling berkaitan akan masyarakat yang berkelanjutan atau entitas bisnis membuat adanya tantangan akuntansi dan standardisasi pelaporan berkelanjutan. Standar pelaporan TBL telah diusahakan dibuat organisasi non profit bernama Global Reporting Iniciative (GRI). GRI membuat protokol mengenai pelaporan TBL bagi perusahaan yang ingin mengungkapkan secara sukarela, panduan yang digunakan juga bersifat sukarela. GRI menyusun indikator yang harus dilaporkan perusahaan yang menggunakan standar pelaporan TBL yang terdiri dari indikator kinerja ekonomi, indikator kinerja lingkungan, dan indikator kinerja sosial dimana masing-masing kategori memiliki aspek-aspek yang harus diungkapkan oleh perusahaan untuk melaporkan pelaporan TBL. Dari panduan yang diberikan oleh GRI, terdapat ekspektasi bahwa pelaporan menjadi dapat dibandingkan (Sherman, 2010).

Fowler et al (2003) memberikan beberapa pilihan yang ada dalam pelaporan TBL yang dapat dipilih oleh perusahaan adalah sebagai berikut:

1. Pengungkapan informasi lingkungan dan sosial dalam pelaporan tahunan pada pemegang saham 


\section{JURNAL NOMINAL / VOLUME VIII NOMOR 2 / TAHUN 2019}

2. Laporan lingkungan atau komunitas yang terpisah

3. Laporan lingkungan dan sosial yang terpisah

4. Laporan sosial dan lingkungan yang dikombinasikan

5. Laporan TBL penuh

6. Beberapa bentuk lain komunikasi dengan pemangku kepentingan

Keuntungan adanya standar pelaporan keuangan yang terseragamkan adalah untuk meningkatkan kualitas akuntansi, mengurangi earnings management, dan memfasiltasi investor (Barth dan Lang, 2008). Keseragaman pelaporan TBL dapat dibuat tidak rigid uniformity, namun finite uniformity yang dibuat dengan menyesuaikan kondisi relevan entitas yang bersangkutan.

Aspek penting lain yang perlu dipertimbangkan dalam menentukan kebijakan keseragaman pelaporan TBL adalah dengan mempertimbangkan variasi industri yang ada. Industri yang ada di dunia tidak hanya terdiri dari satu jenis perusahaan saja. Melakukan perbandingan pada industri yang berbeda tentu tidak akan mencerminkan adanya keterbandingan dalam pelaporannya. Penyeragaman dalam hal kesamaan industri terutama pada hal pengungkapan aspekaspek krusial yang perlu diungkapkan tentu akan lebih mempermudah pengguna dalam melakukan perbandingan di antara industri yang ada.

\section{SIMPULAN DAN SARAN}

Permintaan pelaporan keuangan oleh pemangku kepentingan yang tidak hanya berfokus pada laba semakin meningkat. Hal tersebut mendorong pelaporan perusahaan dituntut untuk lebih informatif dan mengarah pada pelaporan keuangan yang lebih komprehensif. Salah satunya adalah Triple Bottom Line Reporting (TBL). TBL merupakan pelaporan yang berfokus pada tiga aspek yaitu manusia, planet, dan laba. Namun demikian, permintaan yang tinggi tidak diiringi oleh penetapan standar yang dikeluarkan oleh dewan yang berwenang. Penelitian ini menyimpulkan bahwa pelaporan TBL masih mengedepankan konsep fleksibilitas sehingga mengurangi keterbandingan antar-entitas. Di lain sisi, penerapan keseragaman dalam pelaporan TBL juga sulit untuk dilakukan karena perbedaan karakteristik negara dan industri pada khususnya. Penelitian ini mendukung adanya penerapan konsep finite uniformity dalam penerapan pelaporan TBL. Hal tersebut dapat ditekankan bahwa TBL dapat dilaporkan sesuai dengan kondisi ekonomi yang relevan. Saran untuk penelitian selanjutnya adalah dilakukannya penelitian empiris mengenai pengaruh implementasi TBL pada keputusan ekonomi seperti investasi baik di tingkat individu maupun korporasi. 


\section{DAFTAR PUSTAKA}

Ball, R. (2006). International Financial Reporting Standards (IFRS): Pros and Cons For Investors. Accounting and Business Research 36: 5-27

Baridwan, Zaki. (2011). Akuntansi dan Pelaporan Berkelanjutan (Sustainability Accounting and Reporting). Orasi Ilmiah dalam Rangka Dies Natalis ke-56 Fakultas Ekonomika dan Bisnis UGM 19 September 2011.

Barth, ME. Landsman, W.R. dan Lang MH. (2008). International Accounting Standards and Accounting Quality. Journal of Accounting Research. Vol 46 No.3.

Belkaoui, Ahmed Riahi. (2000). Accounting Theory $4^{\text {th }}$ Edition. Australia: Thomson Learning

Elkington, John. (2004). The Triple Bottom Line: Does it All Add Up? (Assessing the Sustainability of Business and CSR). Disunting oleh: Adrian Henriques and Julie Richardson. London: Earthscan

Financial Accounting Standards Board (FASB). (1978). Objectives of Financial Reporting by Business Enterprises. Statement of Financial Accounting Concepts No. 1. Norwalk, Conn.: FASB.

Financial Accounting Standards Board (FASB). (1984). Recognition and measurement in financial statements of business enterprises. Statement of Financial Accounting Concepts No. 5. Norwalk, Conn.: FASB.

Financial Accounting Standards Board (FASB). (2010). Conceptual Framework for Financil Reporting. Statement of Financial Accounting Concepts No. 8. Norwalk, Conn.: FASB.

Fowler et al. (2003). Sustainability: A Guide To Triple Bottom Line Reporting. an Association of Australia's senior Finance Executives from the nation's business enterprises: Group of 100 Incorporated
Global Reporting Iniciative. (2006).

Sustainability Reporting G3

Guideliness. Diakses melalui

http://www.globalreporting.org pada

tanggal 28 September 2016 pukul 14.30

Guo, Ying and David C. Yang. (2014). Sustainability Accounting Reporting: A Survey on 30 U.S. Dow-Jones Companies. International Journal of Accounting and Taxation September 2014, Vol. 2, No. 3, pp. 01-15

Hendriksen, Eldon S dan Michael F. van Breda. (2001). Accounting Theory $5^{\text {th }}$ edition: International Edition. Singapore: McGraw-Hill Book Co

Ikatan Akuntan Indonesia (IAI). (2009). PSAK No 01 (Revisi 2009) Penyajian Laporan Keuangan. Jakarta : Dewan Standar Akuntansi Keuangan IAI.

International Accounting Standards Board. (2015). Comparability of disclosures. IASB Agenda ref 11F June 2015 pp 1-21

Jackson et al. (2011). Sustainability and Triple Bottom Line Reporting - What is it all about?. International Journal of Business, Humanities and Technology Vol. 1 No. 3; November 2011 pp 55-59

Khomba, James Kamwachale dan Frans N. S. Vermaak. (2012). Relevance of financial reporting systems: Singlebottom line or triple-bottom line. African Journal of Business Management Vol. 6(9), pp. 3519-3527

Lako, Andreas. (2014). Green Economy: Menghijaukan Ekonomi, Bisnis, dan Akuntansi. Jakarta: Erlangga

Mc Cullers, Levis D. dan Richard G. Schroeder. (1982). Accounting Theory Text and Readings $2^{\text {nd }}$ Edition. Canada: John Wiley \& Sons, Inc

Meek, G. dan S. Sandagaran. (1990). A survey of research on financial reporting in a transnational context. Journal of Accounting Literature 9 pp $52-74$

Milne, Markus J. dan Rob Gray. (2013). W(h)ither Ecology? The Triple Bottom 


\section{JURNAL NOMINAL / VOLUME VIII NOMOR 2 / TAHUN 2019}

Line, the Global Reporting Initiative, and Corporate Sustainability Reporting. J Bus Ethics (2013) 118:13-29.

Ortega, Xiaoli D. (2012). The Trade-Off Between Accounting Comparability and Representational Faithfulness with Mandatory International Financial Reporting Standards Adoption. Dissertation. David Eccles School of Busines, The University of Utah

Rajafi, Lalu Roby dan Gugus Irianto. (2007). Analisis Pengungkapan Laporan Sosial, dan Lingkungan Sebagai Bagian dari Triple Bottom Line Reporting dalam Akuntansi Pertanggungjawaban Sosial Perusahaan: Studi Perbandingan Ratarata Tema Pengungkapan Antar Kelompok Industri yang Terdaftar pada Bursa Efek Jakarta Tahun 2005. TEMA Volume 8, Nomor 1 Maret 2007

Sherman, W. Richard. (2010). The Second Round of G3 Reports: Is Triple Bottom Reporting Becoming More Comparable? Journal of Business \& Economic Research Vol 8 No. 9: pp 59-77.

Shnayder et al. (2015). Putting Your Money Where Your Mouth Is: Why
Sustainability Reporting Based on the Triple Bottom Line Can Be Misleading. PLOS ONE Journal

Simmons, John K. (1967). A Concept of Comparability Financial Reporting. The Accounting Review, October 1967 pp: 680-692

Slaper, Timothy F. dan Tanya J. Hall (2011). The Triple Bottom Line: What Is It and How Does It Work?. Indiana Business Review, Spring pp: 4-8.

Susanto, Yohanes Kurniawan dan Josua Tarigan. (2013). Pengaruh Pengungkapan Sustainability Report terhadap Profitabilitas Perusahaan. Business Accounting Review: Vol. 1.

Suwardjono. (2008). Teori Akuntansi: Perekayasaan Akuntansi Keuangan. Yogyakarta: BPFE

Undang Undang No 40 tahun (2007) tentang Perseroan Terbatas

Wolk, Harry.I., James.L. Dodd, dan John.J. Royzycki. (2013). Accounting Theory: Conceptual Issues in a Political and Economic Environment. California: SAGE Publication. 